\title{
TRPV6 Gene
}

National Cancer Institute

\section{Source}

National Cancer Institute. TRPV6 Gene. NCI Thesaurus. Code C94616.

This gene is involved in the modulation of both calcium transport and signal transduction. 